\title{
Pet Plastic Bottle Waste with Reuse Approach as Interior Pre-Fabrication Modules for Interior Wall
}

\author{
Ignatius Adrian Santana ${ }^{1}$, Dalhar Susanto ${ }^{1}$, Widyarko ${ }^{1}$
}

\begin{abstract}
PET plastic bottle is one of the main source of waste in big cities. This research aims to find out the possibility of reusing PET bottle as pre fabrication wall module material. The pre fabrication concept were offered so that in the construction phase, the instalation of this material will be fast, efficient, and able to minimalize the waste potential. The method to decided the PET bottle specimen was by surveying some sample location in Jakarta to found out the type and capacity of PET bottle waste. Bottle waste that has the highest volume, was selected to be the speciment for further experiment as pre fabrication modul. To determine the strength capacity of this material, some module variation were designed for compressive and flexural strength test. This research is a preliminary experiment to understanding the basic potential of PET bottle as building material. This research expected to support the use of PET bottle waste for other uses in building construction
\end{abstract}

Keywords - reuse, PET bottle, pre-fabrication, module.

\section{INTRODUCTION}

$\mathrm{P}$ ET is a type of plastic often used as foods and beverages package because it does not contain BP-A (bisphenol-A), has melting point at $260^{\circ} \mathrm{C}$, and has no pores, so it is resistant in wet conditions [1].

Jakarta as a big city always need materials to build facilities and infrastructures. But building facilities and infrastructures is highly dependent on the material coming from areas outside Jakarta. Therefore, Jakarta needs to look at the potential that has been exists in the Jakarta area alone and can be used as an alternative material. One of the biggest potential in Jakarta is the amount of garbage produced daily [2].

Based on data from the year 2010 and taken from five municipalities in Jakarta, organic waste, paper waste, and plastic waste was the big three largest garbage generated in Jakarta [3]. The use of PET plastic bottles with this type aims to reduce waste of plastic bottles and to get a replacement material for building that has lightweight and durable characteristics. Researcher sees the potential in PET plastic bottles as component in interior non structural wall. When compared with conventional non structural wall components such as bricks, PET plastic bottles has the advantage of a lighter mass and abundantly available in the Greater Jakarta area. By using lighter and widely available components in the city itself, the use of PET plastic bottles as a component of structural wall can reduce the carbon footprint in the process

of distribution [4] [5] compared to the use of bricks. Furtherm ore, the reuse approach can reduce the distribution process compared to recycled approach.

In the previous studies, PET plastic bottles with reuse approach have been considered for building material and already exist a studies on the combination of PET and concrete [6], mixed with rice husk [7], experimental characterization of Polyethylene Terephthalate (PET) bottle Eco-bricks [8] and Bungalow in Nigeria [9]. But studies to find out about the power of the empty plastic bottle with the approach of reuse as a building component are no yet available. Therefore, this study aim to discover the potential of empty PET plastic bottles as a building component to be developed into pre-fabrication modules. This development could provide an alternative to the use of building materials in the city as a low carbon footprint and reduce untreated waste.

\section{MANUfacturing The Module}

Manufacturing these modules aims to get a formation that can maximize the potential of the PET plastic bottles in urban areas like Jakarta. Furthermore, by arranging the bottles into the module, then the installation will be more efficient because of pre-fabrication system in process to build the wall.

Designing the module begins with deciding the type of bottle that will be used to assemble the module. The bottles used for this study are planned to have the same type. This allowed the modules to have standardized pattern and size. It required a type of bottles which most likely to become trash. The survey held in several locations samples to find a bottle of any type most widely become garbage. By taking two survey areas, which is an office building and a waste treatment facility in Jakarta. Both of those locations were took as samples because of the office building is one of the location in Jakarta that produced big number of waste and waste treatment facility as a place that have treated waste from many locations in Jakarta.

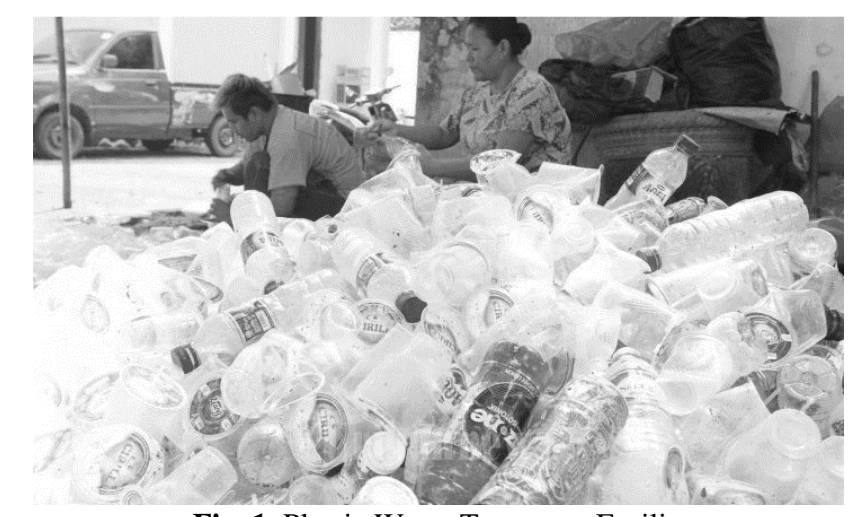

Fig. 1. Plastic Waste Treatment Facility 


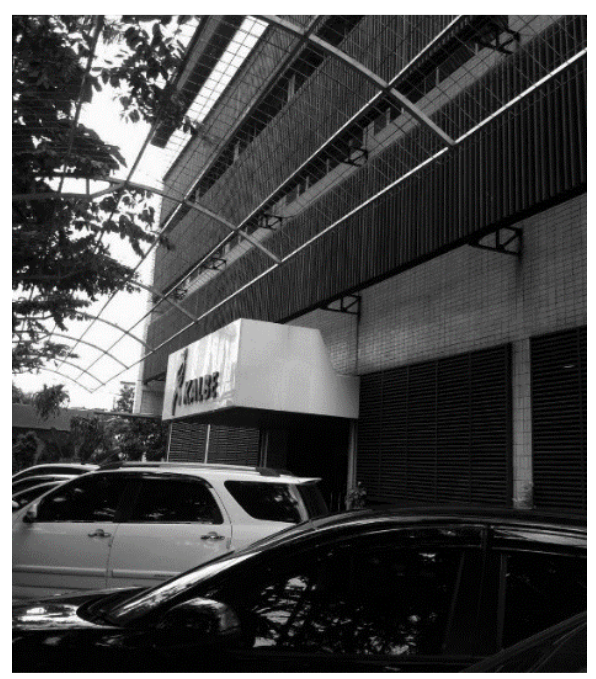

Fig. 2. Office Building

There are 3 types of bottle with the largest quantity from the survey that has been conducted from two different locations:

\begin{tabular}{cccc}
\multicolumn{4}{c}{ Table 1. Quantity of Bottle } \\
\hline \hline Type & Size & Quantity & Mean \\
Bottle A & $600 \mathrm{ml}$ & 495 bottles & 70.71 bottles/week \\
Bottle B & $330 \mathrm{ml}$ & 114 bottles & 16.29 bottles/week \\
Bottle C & $500 \mathrm{ml}$ & 29 bottles & 5.71 bottles/week
\end{tabular}

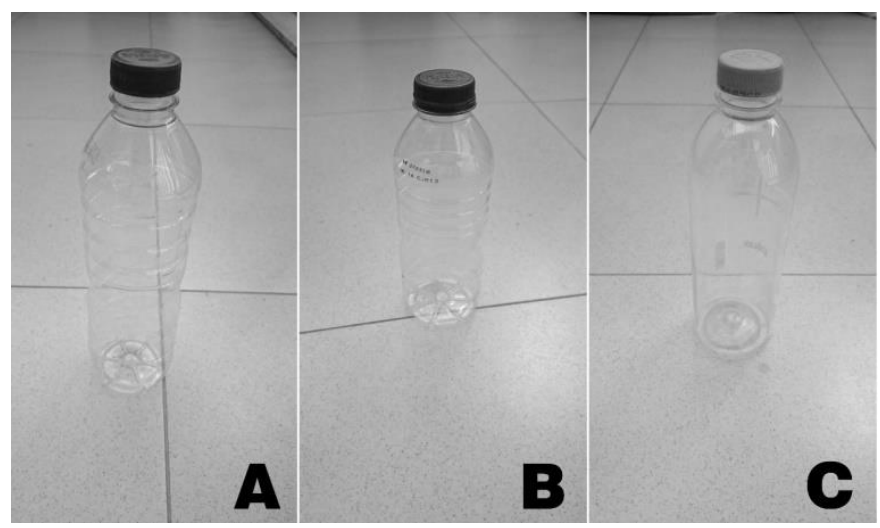

Fig. 3. (A) Bottle A, (B) Bottle B, (C) Bottle C.

From the data that has been obtained, this study will use bottle $\mathrm{A}$ as a type of bottles that most widely available. To determine the module designs, this study use exploration as a method to find patterns and the additional components that deserves to be the bond component between the bottles with the provisions: the ability of the module to stand and attach the bottles tightly. From the results of exploration that has been carried out, it was concluded that to support the establishment of pre-fabricated modules, there are three patterns for the manufacturing of bottles, there are hexagonal, horizontal, and diagonal. While the additional components required are acrylic sheet and galvanized wire. The evaluation of the 6 specimens are introduced into the experiment module:

Table 2. Types of Module

\begin{tabular}{ccc}
\hline \hline Module Specimen Number & Material & Pattern \\
\hline Module A & Wire & Hexagonal \\
Module B & Wire & Horizontal \\
Module C & Wire & Diagonal \\
Module D & Acrylic & Hexagonal \\
Module E & Acrylic & Horizontal \\
Module F & Acrylic & Diagonal \\
\hline \hline
\end{tabular}
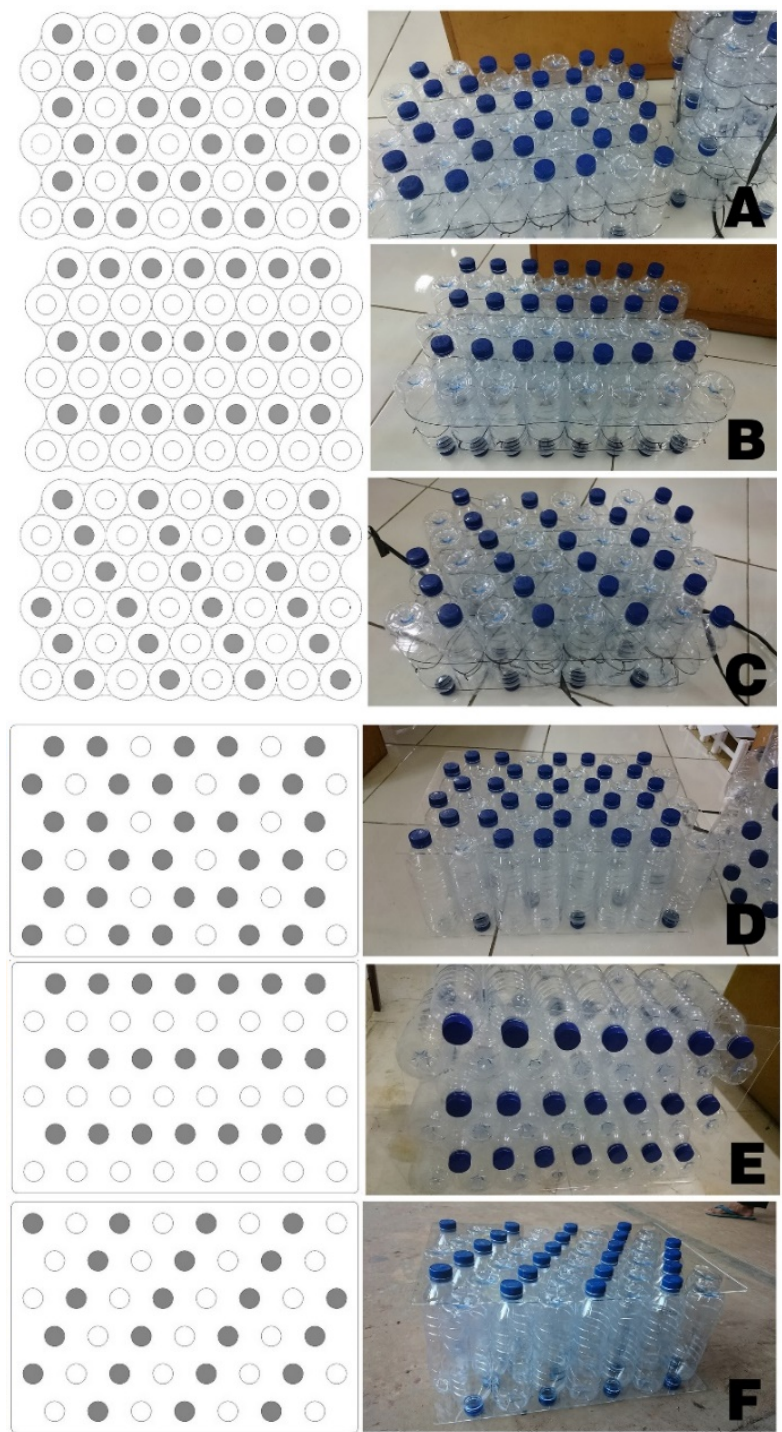

\section{EXPERIMENTAL CONSIDERATION}

Tests were conducted on the compressive and flexural strength of the modules. Compression test aims to determine how adaptable are the modules when receiving a load coming from the top of the module as the dead load of material module itself. While flexure test is to determine the strength of the module when it receives the pressure coming from the 
front side of the module such as when receiving a blows of the wind or human movement.

\section{A.Compression Test}

At the first time, press test was conduct in the laboratory structure and material in order to obtain feedback on the testing process and flexure test. But in the testing process by using a laboratory flexure tests, the instrument can not found the compressive strength of this module. Thus this study switched to alternative testing method to get the compressive strength.

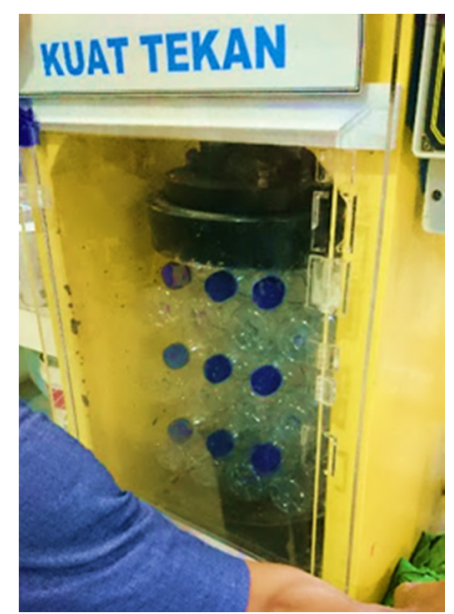

Fig. 4. Laboratory Compression Test

Alternative compressive test instrument made from plywood, box-shaped, with dimension $40 \mathrm{~cm}$ x $29 \mathrm{~cm}$ x 38 $\mathrm{cm}$. The instrument role is a module holder and size gauge of module.

Loads in this test were concrete bricks that has weight between $2.38 \mathrm{~kg}$ to $2.78 \mathrm{~kg}$. Therefore, testing is also done on a flat floor (as evidenced by the use of water pass) and indoors to avoid the blows of wind.
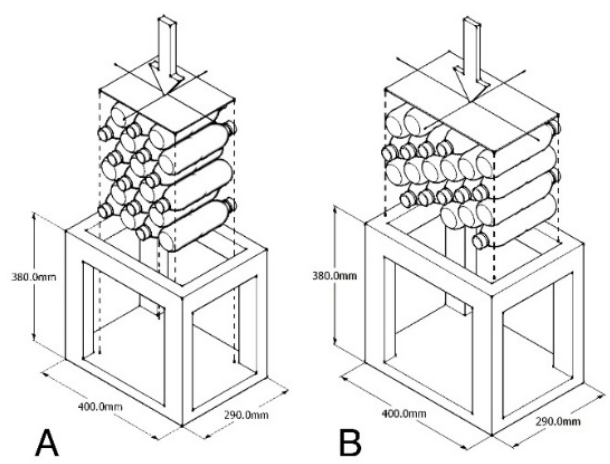

Fig. 5. (A) Compression Test Long Side, (B) Compression Test Wide Side.

The test was conducted by noting the changes that occur in every transformation of the module. The changes that recorded were:

- Load added,

- Decrease of module surface,

- Widening the side of the module.
The purpose of noting any changes were to know the nature of the module when it loads and to determine the maximum load that can be received by each module. Compression tests were performed twice on each alternative, in order to test both sides of the modules (the long side, and a wide side) with two different modules. Both modules have the same size and binding method to ensure the tests would be done with a good condition module.

\section{B. Flexure Test}

In alternative bend, the test was using an instrument for holding the module to support the process of the test when the module was receive loads.

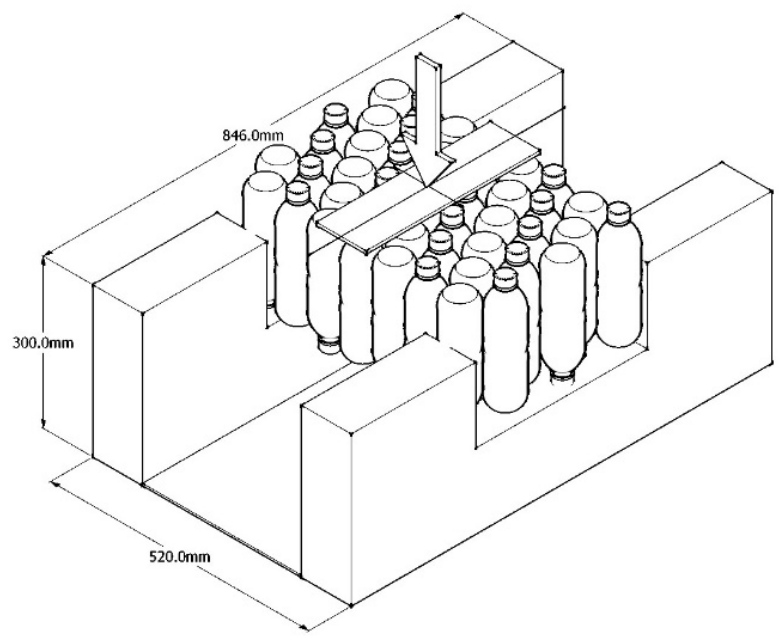

Fig. 6. Flexure Test

Loads in this test were using the concrete bricks that has weight between $2.38 \mathrm{~kg}$ to $2.78 \mathrm{~kg}$. The loads were place on the top middle of the module and used a wood plank $(10 \mathrm{~cm} \mathrm{x}$ $35 \mathrm{~cm}$ ) as pedestal. The pedestal were use as distributors of load pressure onto the module. The test was conducted by noting the changes that occur every transformation of the module. The changes that recorded were:

- Load added,

- Decrease of module surface, 


\section{TEST RESUlts}

Table 3. Tests result

\begin{tabular}{|c|c|c|c|c|c|c|}
\hline & \multicolumn{2}{|c|}{ Press Test (long side) } & \multicolumn{2}{|c|}{ Press Test (wide side) } & \multicolumn{2}{|c|}{ Bend Test } \\
\hline & \multirow{2}{*}{ Max. Load } & Decrease & \multirow{2}{*}{ Max. Load } & Decrease & \multirow{2}{*}{ Max. Load } & Decrease \\
\hline & & Widening & & Widening & & Widening \\
\hline Module A & $13.4 \mathrm{~kg}$ & $\begin{array}{l}1.6 \mathrm{~cm} \\
0.1 \mathrm{~cm}\end{array}$ & $41.9 \mathrm{~kg}$ & $\begin{array}{l}7.5 \mathrm{~cm} \\
0.8 \mathrm{~cm}\end{array}$ & $17.6 \mathrm{~kg}$ & $4.8 \mathrm{~cm}$ \\
\hline Module B & $36.48 \mathrm{~kg}$ & $\begin{array}{l}5.8 \mathrm{~cm} \\
0.4 \mathrm{~cm}\end{array}$ & $44.62 \mathrm{~kg}$ & $\begin{array}{l}5.5 \mathrm{~cm} \\
0.7 \mathrm{~cm}\end{array}$ & $17.6 \mathrm{~kg}$ & $4.2 \mathrm{~cm}$ \\
\hline Module C & $18.6 \mathrm{~kg}$ & $\begin{array}{l}2.1 \mathrm{~cm} \\
0.4 \mathrm{~cm}\end{array}$ & $72.68 \mathrm{~kg}$ & $\begin{array}{c}6.4 \mathrm{~cm} \\
2 \mathrm{~cm}\end{array}$ & $20.12 \mathrm{~kg}$ & $4.2 \mathrm{~cm}$ \\
\hline Module D & $80.92 \mathrm{~kg}$ & $\begin{array}{l}2.3 \mathrm{~cm} \\
1.1 \mathrm{~cm}\end{array}$ & $59.68 \mathrm{~kg}$ & $\begin{array}{l}2.9 \mathrm{~cm} \\
1.1 \mathrm{~cm}\end{array}$ & $43.26 \mathrm{~kg}$ & $2.7 \mathrm{~cm}$ \\
\hline Module E & $73.06 \mathrm{~kg}$ & $\begin{array}{l}2.3 \mathrm{~cm} \\
1.1 \mathrm{~cm}\end{array}$ & $86 \mathrm{~kg}$ & $\begin{array}{l}2.3 \mathrm{~cm} \\
1.3 \mathrm{~cm}\end{array}$ & $56.58 \mathrm{~kg}$ & $4.2 \mathrm{~cm}$ \\
\hline Module F & $94 \mathrm{~kg}$ & $\begin{array}{l}2.3 \mathrm{~cm} \\
0.7 \mathrm{~cm}\end{array}$ & $94 \mathrm{~kg}$ & $\begin{array}{c}2.4 \mathrm{~cm} \\
1 \mathrm{~cm}\end{array}$ & $59.18 \mathrm{~kg}$ & $4.6 \mathrm{~cm}$ \\
\hline
\end{tabular}

The result of these studies shows that modules that used acrylic (module D, E, and F) as the bonding component was stronger than another modules that used wire as the bonding component. Therefore, module $\mathrm{F}$ has the best result in two press test (long press test and wide press test) and bend test.

\section{CONCLUSION}

The use of bottle for building component has been started since the 60's by Heineken [9]. The glass bottle produced by Heineken were designed so that after the actual use of the bottle, it can be used as wall. Unfortunetly, this inisiation was discontinued because environmental issues has not been consider important by society. Unlike nowdays, society awareness to maintain the environment from waste such as PET bottle started to grow. This researched is expected to encourage PET bottle producer to design their bottle to be reuseable as building material after its original use. This research aim to find a new method to use PET bottle as non structural wall. This is a preliminary research that focused to get a strength capacity as prefabrication module. Further research is needed to determine its fixed method to find standardized result and feasibility, such as noise reduction performance and interconection system as non structural wall prefabrication module.

\section{REFERENCES}

[1] Institut für Arbeitsschutz der Deutschen Gesetzlichen Unfallversicherung (IFA), "Polyethylene terephthalate," 2014. [Online]. Available: http://gestisen.itrust.de/nxt/gateway.dll/gestis_en/530566.xml?f=templates $\$ \mathrm{fn}=\mathrm{de}$ fault.htm\$3.0. [Accessed 1 November 2015].

[2] Kompas, "Krisis Sampah Berulang," 5 November 2015. [Online]. Available:

http://megapolitan.kompas.com/read/2015/11/05/15090001/Krisis.Sa mpah.Berulang. [Accessed 1 Desember 2015].

[3] Dinas Kebersihan Pemerinta Provinsi DKI Jakarta, "Data Pengelolaan Kebersihan Triwulan I 2010," February 2011. [Online]. Available: http://inswa.or.id/wp-content/uploads/2012/11/Bab-5-KondisiSistem-Pengelolaan-DKI-Jakarta-2010-20112.pdf. [Accessed 20 April 2016].

[4] T. Wiedmann and J. Minx, "A Definition of 'Carbon Footprint'," $C$. C. Pertsova, Ecological Economics Research Trends, vol. 1, pp. 1-11, 2008.

[5] A. Leonard, The Story of Stuff, New York: Free Press, 2010.

[6] R. Siddique, J. Khatib and I. Kaur, "Use of recycled plastic in concrete: A review," Waste Management, vol. 28, no. 10, pp. 18351852, 2008.

[7] N.-W. Choi, I. Mori and Y. Ohama, "Development of rice husksplastics composites for building materials," Waste Management, vol. 26, no. 2, pp. 189-194, 2008.

[8] J. Taaffe, S. O’Sullivan, M. E. Rahman and V. Pakrashi, "Experimental characterisation of Polyethylene Terephthalate (PET)," Materials and Design, vol. 60, pp. 50-56, 2014.

[9] T. Laylin, "Africa's First Plastic Bottle House Rises in Nigeria," 11 Juli 2011. [Online]. Available: http://inhabitat.com/africas-firstplastic-bottle-house-rises-in-nigeria/. [Accessed 1 Desember 2015].

[10] A. Bokern, "The House of a Thousand Headaches," 2009. [Online]. Available: http://www.annekebokern.com/pdf/athousandheadaches.pdf. [Accessed 3011 2015] 